\title{
Reflection as a Component of an Intercultural Educational Project: Case Study in the Pushkin State Russian Language Institute
}

\author{
Arina Zhukova ${ }^{1 *}$, Tatiana Kudoyarova ${ }^{1}$, Ivan Leonov ${ }^{1} \&$ Ekaterina Budnik ${ }^{2}$ \\ ${ }^{1}$ Pushkin State Russian Language Institute \\ ${ }^{2}$ Moscow State Linguistic University
}

\begin{abstract}
The abstract should provide a comprehensive summary of the work performed, including the motivation of the research, aim of the research, methods of the research, main results of the research, contribution to the theory and practice of the research. For nine years, the Pushkin State Russian Language Institute has been successfully using the educational and teaching technology intercultural educational project (IEP) - in teaching Russian as a foreign language. The goal of the project is to ensure intercultural communication among all the participants: foreign students and Moscow schoolchildren. During this project, the audience gets acquainted with the differences between languages and cultures. The specifics of this format of educational and design activities is determined by the relevant factors: the collaboration of foreign students studying Russian, and the other -, native speakers of the Russian language and culture. For the Moscow schoolchildren, the project is a part of their training activities, for the students - an extracurricular educational event. Also, the project concept assumes that both students and children can also become more familiar with (for example, Finland and Vietnam, etc.) each other's cultures. During the implementation of this technology, representatives of 34 countries took part in it, as well as more than 5,000 Moscow schoolchildren and teachers. The components of reflection are the ability to comprehend the mechanisms that contribute to obtaining certain results; ability to analyze personal cognitive opportunities. Reflection in the educational process implies a thoughtful or sensually experienced process of awareness by the subject of his academic activities. The article aims to present the reflection component of IEP that the authors of the article draw special attention. Participation in the preparation and implementation of activities that demonstrate the results of students' reflection, reflects the availability of intercultural communication at different levels of language proficiency, enables participants to feel confident in their abilities, motivate them, and increase the effectiveness of language learning. Authors hope that theoretical and practical aspects will contribute to the methods of teaching any foreign language.
\end{abstract}

Keywords: reflection, intercultural communication, educational technology, international educational project

\section{Introduction}

In the modern world, gripped by opposing processes - globalization and the desire for ethnocentrism (Aisman, 2018), the ability to successfully conduct a dialogue with representatives of other cultures on the principles of tolerance and mutual respect plays a crucial role. Teaching "culture as a dialogue of cultures" (Bibler, 1997, p.7) is becoming a necessary component of modern education at all levels, which poses the problem of an adequate choice of educational technologies and formats for teachers. This is of particular importance for teaching foreign languages, which "as a phenomenon of constantly learning with another culture in the course of linguistic communication is intercultural in nature" (Berdychevsky, 2012, p.21).

Intercultural didactics, the purpose of which is to study ways of building the educational process on the principles of the dialogue of cultures, and the subject is "the interaction of matters of learning in an intercultural 
context" (Petrikova, 2015, p.18). It sets its task the formation of a personality that can "acquire the qualities of a mediator of cultures losing their own cultural identity" (Elizarova, 2001, p.22).

The purpose of intercultural education should be the mastery of a universal toolkit suitable for interaction with any foreign culture: "The object of study should not be the culture of the target language, but the methods of mastering other cultures" [Byram, 1997, p.18]. The basis of such a toolkit is, in our opinion, intercultural reflection - a comparative understanding of the facts of someone else's and one's own culture and one's reaction to communication with "others".

The authors of this article focus on the situation of teaching Russian as a foreign language to foreigners in Russia, the country of the target language. However, being in a foreign cultural environment does not guarantee the development of intercultural competence. At the same time, intercultural learning, pedagogical support of staying in the environment has a positive effect on these qualities of students (Pedersen, 2010, p.64).

From this point of view, we distinguish many problematic issues: a) cohabitation of representatives of large diasporas (Chinese, Vietnamese), as well as a developed "national" infrastructure, lead to the fact that students communicate mainly with their compatriots; b) the disproportion in the number of representatives of different nationalities forces universities to form mono-national groups. Thus, foreign students are not sufficiently involved in the language, in communication with the host culture media (excluding teachers) and have no incentive to use a studied language as a means of intercultural communication.

These difficulties are partly removed by creating a linguodidactic language environment - a controlled language environment, the fruit of pedagogical efforts. The advantage of such a "man-made" environment is associated with anticipation, selection and planning of sources and stages of assimilation of linguistic and cultural information by foreign speakers (knowledge is drawn from the natural linguistic environment spontaneously and uncontrollably) (Orekhova, 2004, p.14-15). In our opinion, linguodidactic language should be built in such a way as to give a foreigner an "outlet" to the natural language environment, to create situations of active intercultural interaction in the target language with speakers of the host and other linguistic cultures.

In our opinion, an intercultural educational project is an effective pedagogical technology, in the implementation of which three parties are involved: representatives of at least two different linguocultures studying at the Pushkin Institute, as well as carriers of the receiving (Russian) linguoculture. The organization and preparation of the project are carried out under the guidance of a teacher-tutor. The models of interaction with students implemented by the teacher depend on the level of their language training, experience of living in Russia, cultural and personal characteristics and vary at each specific stage of the project.

The authors wrote in detail about the advantages of this design technology and the difficulties associated with its use in the following paper (Zhukova, et al, 2019). Here we note the main thing: the creation of a situation of real multilateral intercultural interaction, which requires collective and individual creative work for its success, the responsibility of each participant for the overall result turns the studied language into a means of solving communicative problems - achieving the goals of the project.

One of the essential components of the project method is the reflection of the project participants about their activity, its meaning and significance for personal development.

Reflection is also a prerequisite and an integral part of intercultural competence. Alien culture is cognized with the help of images of native culture, which in the process of such cognition is realized and rethought (Tarasov, 1996). Thus, in intercultural teaching of a foreign language, the native language and native culture become a necessary component of intercultural communication, and reflection on the facts of the native culture is a necessary condition for understanding the facts of the alien. In the development of intercultural competence, " 2 main stages can be distinguished: 1) awareness of the orientation system characteristic of the native culture 
(self-awareness); 2) awareness of the significance of cultural facts in the process of communicative interaction (cross-cultural awareness) (Berdichevsky, 2012, p.21).

A fundamentally important element of the discussed pedagogical technology is the inducement of the project participants to reflection in both of the above aspects.

\section{Methodology}

In our research, we used the methods of reflection and self-observation. Reflection (from the Latin reflexio turning back) is interpreted as "reflection, self-observation, self-knowledge" (Modern encyclopedia). Reflection is of particular importance in the teaching (an Introspection as a Methodology ... 2007), "is an important feature of professionally important personality of the teacher" (Azimov, Shchukin, 2018, p.281). Thus, reflection is understood as the individual's appeal to his inner world, his experience, activity, experiences, etc. - to everything that he saw, heard, read, did, thought, felt, etc. - and how, why and why he sees, does, thinks, feels.

We are close to the position of A. Khutorsky, who believes that reflection in teaching is a thought-activity or sensory-experienced process of the subject of education realizing his activity (Khutorskoy, 2003). In the educational process, the reflection of not only the teacher but also the student is important. With different positions, all methodologists agree that the formation of the ability to reflect in the learning process affects the formation, education and self-education of the individual.

There are several types of reflection, depending on its form and content. Reflection can be orally and in writing, group second and individual second. Following the goal, emotional reflection, a reflection of activity and reflection of the content of the material are distinguished.

In the structure of the described educational technology - an intercultural educational project - it is possible to distinguish: a) individual emotional reflection of international students, b) reflection on their activities during the preparation and implementation of the project, c) reflection of the content of materials that they prepare for events, d) intercultural reflection based on the experience of intercultural communication. In this regard, the concept of self-observation was also essential for us, which can be considered one of the components of reflection.

The method of self-observation (introspection) is based on the individual's ability, known in psychology, to fix his psychological processes, that is, to observe his behaviour and emotions as if from the outside (from the Latin "introspecto" to look inside). It is believed that the development of the ability for conscious self-observation is a means of human self-development, one of the conditions for his personal growth. During self-observation, a person is exposed to his own emotions, feelings, thoughts, ideas that require exceptional inner work "to comprehend, interpret, and understand" (Slobodchikov and Isaev, 1995, p.109). Self-observation is also essential in pedagogy, as it allows recording the reactions of students and teachers to the educational process to assess the degree of its effectiveness. Finding themselves in a foreign country, in an unusual academic and everyday discourse, international students record cross-cultural inconsistencies that cause their surprise, favourable or adverse reactions. However, this fixation is often unconscious and can create barriers to communication rather than remove them.

Constant intercultural communication makes it possible to carry out intercultural self-observation, fixing one's reactions to the phenomena of other linguistic cultures. Self-observation should become the basis, on the one hand, for a more in-depth study of the culture, traditions and customs of the country, and on the other hand, for the development of intercultural sensitivity and overcoming barriers in communication between representatives of different cultures. At our institute, from the very first day, a student finds himself in a multicultural 
environment, the dominant of which is Russian culture. In this regard, conditions are created for the implementation of self-observation against the background of different linguocultures.

Russian scientist S. Stepanov has allocated skills are important is, for intercultural communication: 1) the willingness and ability of a person to creatively interpret and overcome the problem-conflict situations; 2) the ability to acquire new meanings and values; 3) the ability to adapt to unique systems of relationships; 4) the ability to pose and solve non-ordinary practical problems (Stepanov, 2000, p. 54-60). From our point of view, all these qualities are essential for a foreign student living and studying in a new culture for him. Therefore, in the project is, "Horizons of Friendship", we actively use different types of reflection, aimed at forming of all listed skills.

\section{Study}

The intercultural educational project "Horizons of Friendship" involves the preparation and conduct of events for Moscow schoolchildren and teachers by foreign representatives of different linguistic cultures. The students from 2-4 countries represent their countries, languages and cultures in an interactive way. The concept of the project, according to which representatives of different countries (including those whose historical and cultural ties are not obvious) become participants in a particular event, makes it possible for international students to get to know each other better. In the process of preparing the event, students from different countries communicate with each other in Russian, which strengthens the ties between them. Thus, within the framework of each event, a multilateral intercultural dialogue is being established, one of the sides of which is the carriers of the "host" linguistic culture.

The project has been implemented at the Pushkin Institute since 2011. During this time, 27 events were held, in which more than 5,000 Russian schoolchildren and teachers took part, as well as representatives of 32 states students and interns from the following countries: Algeria, Bulgaria, Bosnia and Herzegovina, Brazil, Hungary, Vietnam, Gabon, Ghana, Greece, India, Indonesia, Iran, Italy, China, Colombia, Cuba, Latvia, Mali, Mexico, Mongolia, Myanmar, Poland, Turkey, Russia, Romania, Serbia, Slovakia, Slovenia, Ukraine.

The project has two main goals: 1) educational for students, it consists in developing their intercultural communicative competence through the creation of communicative situations that contribute to the development of motivation and improve the quality of language training; 2) educational for schoolchildren, it is associated with the development of cognitive competence, the formation of tolerance and an idea of the diversity of the world.

Project events are held in two of the most effective but different formats: classical and thematic. These formats meet the tasks of developing intercultural competence in students and schoolchildren.

The classical format has a mindset for a comprehensive and multifaceted acquaintance of students with the cultures and traditions of different countries and peoples. Preparing for such a format, international students try to give schoolchildren a complete picture of their country. Most often, this applies to aspects such as the geographical location of the state, climate features, natural conditions. Also, they try to present information about the most important monuments of history and culture, perform national songs and dances, and demonstrate traditional costumes. Also, their presentation may include information about national etiquette, holidays, traditional cuisine, folklore customs and rituals that have retained their relevance in the modern era. Quite often, within the framework of the classical module, a mini-lesson of a foreign language is held, during which students have the opportunity to learn a few words in a foreign language for them. Besides, the classical format involves a master class, in which schoolchildren have the chance to more deeply master one or another side of a culture unfamiliar to them, for example, learn the elements of traditional dance or national game, learn a song or poem in a foreign language, use in the process communication sign language. 
For example, at a meeting dedicated to the cultures of Vietnam and India, schoolchildren took part in two masterclasses: they got acquainted with several sounds of Vietnamese phonetics, which is not quite usual for a Russian speaker, and also mastered some aspects of Indian dances and outdoor games. Such a combination of intellectual and physical activity, firstly, helped to increase the motivation of schoolchildren when getting to know the cultures of other countries, and secondly, it had a positive effect on the removal of communication barriers between international students and project guests.

The thematic format assumes an in-depth disclosure of a particular aspect of culture. Schoolchildren, with the help of international students, get an idea of how a particular cultural phenomenon is represented in different nations. The following thematic events aroused the most significant interest: "Language of family communication in different countries", "Adventures of foreigners in Russia: from surprise to understanding", "My first day in Russia".

So, the students' speech/performance consists of two modules: a) verbal and visual presentation of certain features of their culture and language in comparison with Russian culture and language. The verbal presentation includes the story of students and an interactive appeal to schoolchildren in a game format (mini-quiz, comic questions, learning etiquette phrases, gestures); b) a mini-master class, during which students acquaint school children with the bright cultural peculiarity of their country: for example, students from India learned a fragment of the national dance with schoolchildren, the Chinese introduced children to the art of calligraphy, the Japanese made them participants in the tea ceremony.

The project includes two stages. The first stage - preparatory - is crucial from the point of view of the implementation of the first goal of the project. It consists of: a) diagnostics of the participants in terms of the level of language proficiency, b) selection of material for the speech, c) development of the scenario of the speech; c) preparation and editing of presentation materials, props and text; d) rehearsals, during which the prepared materials and script moves are tested. At this stage, it is crucial for the teacher to ensure the interaction of participants representing different cultures, languages and countries, often with varying levels of Russian language proficiency (see about this in [Zhukova, Kudoyarova, Leonov, Budnik, 2019]).

It is at this stage that the teacher, who plays the role of a tutor, guide, assistant, creates conditions for intercultural reflection of students, the search and selection of similar and contrasting features and phenomena of Russian and native culture, primarily based on the experience of the student himself. Communication with students takes place in the form of individual and group "reflective" conversations. With leading questions, the teacher helps students to formulate those striking cultural and linguistic inconsistencies that will become the starting point of a discussion about our countries. As part of the preparatory stage, interesting facts are revealed that emphasize the identity of cultures. Of course, during the existence of the project, many countries have been repeated many times, but the scenario of the story about them has never been duplicated. This is because each time we try to proceed from the personal impressions and knowledge of the students, identified based on "reflective" conversations. If necessary, the teacher can recommend additional material to students, but the decision on what the content of the presentation will be is left to the students

For example, every year, Chinese students participate in "Horizons of Friendship", and each time we hear a story about China based on "new parallels". In this sense, we can say that teachers are luckier than schoolchildren, who cannot be participants in absolutely all of our events. So, at one of the meetings, the student played the traditional Chinese instrument Guzheng and compared it with the Russian folk instrument gusli. At another meeting, Chinese students played out a Chinese fairy tale and then compared it to Russian folk tales. Another group of students preferred to read and analyze Chinese love poems to show how different poetic images are in Russian and Chinese lyrics. 
Comparative intercultural reflection is of particular importance in thematic projects. For example, in preparation for the thematic event "The language of family communication in different countries", students were asked to tell about the appeals to their peers or elders accepted in their cultures, the possible use of nicknames in a family or friendly communication (in Russian it is a common thing to use animal names "zaichik, zaya" [hare], "rybka" [fish], "kotik" [cat], etc.). The participants of the project were asked the following questions: "What do you know about the peculiarities of communication between children and parents in Russian families? How is it customary to address older relatives in Russia: "you"-in singular or plural*? What household names/nicknames can be prevalent in Russian family communication? Have you ever witnessed such communication? "

*In Russian grammar second-person pronouns have a singular and a plural form. To say 'you' and mean one person, say ты (ti). To refer to more than one person, use вы (vi).

It is important to emphasize that the teacher, having a sizable intercultural experience, asks such questions, the answers to which can become potentially significant for the dialogue of cultures, with the student-foreigner associating familiar aspects of his own culture that he saw in Russia. In several cases, this causes surprise, misunderstanding, promotes the search for an explanation of the reasons for this discrepancy, but in most cases, acceptance of what is seen occurs.

Here are some more examples of intercultural reflection obtained during conversations with international students. So, a student from China shared how she changed the understanding of the Russian communicative features. In the first months after her arrival, Russia surprised her and even shocked that Muscovites rarely smile on the street at a stranger. From the beginning, she thought that Russians do not smile only in winter, and this is due to climatic conditions, but in summer, she observed the same feature. Later, the girl realized that a smile in Russia is a particular sign of friendly disposition and trust; it is addressed exclusively to a loved one and is a manifestation of special sympathy for him.

Another student from China said she would instead ask an older woman than an older man on the street. From her point of view, all Russian grandmothers are "kind and sympathetic", and grandfathers are "too serious".

Many students from Asian countries (Vietnam, Indonesia, China, Korea, Japan) drew attention to the fact that when communicating with interlocutors from Russia, they may experience discomfort during direct eye contact with them. The foreign student tries to look down or away, while in the European tradition, the gaze of the participants in the conversation should be directed towards each other.

Also, students from Southeast Asian countries note the difficulties they face when contacting teachers. According to Russian etiquette, a student addresses a person who is older in age and status by name and patronymic name, which is difficult for foreigners to perceive. Very often, a student from China or Vietnam uses the traditional for their culture address "teacher" concerning the teacher of a Russian university. Such treatment does not correspond to the norms of etiquette that are accepted in Russian higher education.

The second important aspect at the stage of preparing an event for us is the addressee factor. We hold events for children 10-15 years old, and we understand that the story about countries should be dynamic, should arise interest and curiosity, which means that vivid and memorable images and examples are needed. To predict such a reaction from the addressee, teachers also carry out intercultural reflection, answering the question: "What surprised me the most in the story about the country? What is similar to what is in Russia, and what is very different? Will this surprise today's teenagers? "We ask similar questions to students, motivating them to choose and present material creatively. The results of this joint reflection help to make the performance more vivid and expressive.

For example, talking about his motherland Serbia, a student showed schoolchildren a picture of a snow-covered winter village and asked the question: "Is this village in Russia or Serbia?". The picture showed wooden village 
houses and birches - a landscape traditional for Russian culture. The schoolchildren guessed that the photo was a Serbian village, due to the unusual shape of a wicker fence. At the same time, they realized that there is also winter and snow and that the nature of Serbia is similar to Russia. Talking about the Serbian language, the students showed by examples that in our languages many words are the same in spelling and meaning, but some words sound and spelt the same, but mean different things - the so-called "false friends of the translator". On this, the students built a game of riddles, for example: why in Russia you can sit on a chair, but in Serbia, you can live in it? Answer: word pun: because this piece of furniture (in Russian - a chair) in Serbian is denoted by the word capital (in Russian, the capital is the central city of the country).

Talking about Korea, Korean students showed a photograph in which many small black clay barrels were standing right on the street in the snow, and asked the students to guess what it looks like in Russia. It turned out that Koreans store pickled cabbage in such barrels in winter. In Russia, cabbage is salted and stored in wooden or plastic barrels in the cellar.

With students from Vietnam, the whole story was built on the image of rice. With the help of photographs and examples, they showed that for a Vietnamese, rice is the same as wheat for a Russian. Even outwardly, the ears of rice and wheat are similar. Just like rice, salty and sweet dishes, flour, spaghetti are made from wheat in Russia, and bread is baked. This time, we made a gastronomic journey through Vietnam, learning the difference between rice, vegetables and meat dishes in three large regions of Vietnam.

Reflection of students at the preparatory stage allows to solve two problems simultaneously: a) to promote the development of their intercultural sensitivity, intercultural competence and skills of intercultural selfobservation; b) to contribute to the development of their communicative competence based on solving real (tricky!) communicative tasks.

\section{Experiment}

To find out how successfully the event meets the set goals and objectives, what is its significance in terms of creating favourable conditions for intercultural dialogue, as well as removing barriers in the process of communication between representatives of different countries and cultures, we survey the event participants - a kind of post-reflection.

Intercultural introspection is crucial to us; therefore, attention is focused both on the individual psychological reactions of the informants, and on their responses as representatives of their own linguistic culture.

Based on the answers of international students to these questions, the teacher can compose/expand/clarify the portrait of the foreign communicant and identify how the participation in the project influenced his adaptation in the country, to increase the level of the Russian language proficiency. In the course of the survey, international students are asked questions related to their perception of Russian schoolchildren, comparing them with children and adolescents of their native country. Separate questions relate to the difficulties that arose in the process of preparing and participating in the project, assessing their results of participation in the event and prospects, and also aimed at identifying the opinion of foreigners about the need to include such projects in the educational process.

In the last two surveys, 40 students took part; they were from China, Vietnam, South Korea, Indonesia, Mongolia, Romania, Congo, Serbia, aged 20 to 27. The experience of participating in projects of this kind is different for everyone, from one to five events.

When analyzing the results of the questionnaires of schoolchildren and students, we revealed an indicative tendency: both the guests of the project and international students before the event noted feelings of 
awkwardness or excitement that they experienced before meeting each other. For example, foreign students noted that they do not know what would be interesting for schoolchildren and students to learn about their country, felt apprehension due to insufficient knowledge of the Russian language, believed that schoolchildren would meet them coldly, indifferently, without emotion. Analyzing their feelings after a performance on stage, a master class and informal communication with children, foreigners noted that they were pleased with the activity of the audience, openness, and a tendency to communicate. The question in the questionnaire was formulated as follows: "What surprised you in the behaviour of Russian schoolchildren"? Most of the respondents were surprised by the activity of the guys (15 people), their openness ( 5 people). Also, international students pointed out the interest of schoolchildren in comprehending a new culture for them ( 3 people), their desire and ability to freely express their thoughts ( 5 people), the desire to talk about the traditions of their country when comparing certain cultural phenomena (for example, communication in the family, holidays celebrations, presenting gifts, and so on).

The questionnaire addressed to international students included a question about the difficulties they encountered in preparing for the event. The answers showed that many respondents experienced difficulties in selecting material and finding ways to present it (15 people), as well as linguistic problems (13 people).

One of the questions was related to the peculiarities of their countries and cultures, which might be familiar to Russian schoolchildren. Students were asked to name these features. The respondents answered that schoolchildren have the right ideas about oriental cuisine (9 people), capitals (4 people), hieroglyphs (4 people), most important historical events ( 2 people), sights ( 2 people).

To reveal the reflection of foreign participants about what turned out to be familiar and exciting for them in Russian reality, the developers of the questionnaire asked the following question: "If you held such events about Russia in your country, what would you tell the students about?" The most frequent answers were: Russian cuisine (12 people), literature and folklore (11 people), attractions (9 people), climate, nature (7 people). Further, in descending order, were named national holidays, language system, historical figures and achievements in cinematography.

Assessing the personal result of participation in the project, foreign students noted that communication with Moscow schoolchildren helped them in terms of learning the Russian language, gave a deeper and more systematic understanding of their own culture, helped to overcome fear and anxiety, and also formed an understanding that dialogue with children is not easily possible, but is exciting and useful to them.

Also, international students have been suggested issues related to the identification of their desire to continue participating in activities of this kind. The vast majority of respondents (37 persons) affirmatively responded to this question, and the few answered negatively, motivated their answer by language difficulties and worrying.

Post-reflection of international students is vital for teachers not only as an indicator of the success/failure of each specific event but also to verbalize intercultural reactions, fix them in the minds of the students themselves. From our point of view, this improves the quality of intercultural and linguistic competencies.

We meet with the addressee of the "Horizons of Friendship" project - Moscow schoolchildren - only at the stage of the event. Nevertheless, we consider it important to stimulate their reflection before contact with representatives of other linguistic cultures, at least to a minimal extent. For this, teachers conduct a study of the primary ideas of schoolchildren about countries and their inhabitants. As a rule, before the start of the event, a mini-survey of schoolchildren is conducted, who are invited to name some associations associated with the countries participating in the meeting. Most often, their associations relate to the geographic location of the state ("far", "south", "west", "near Russia"), climatic conditions ("cold", "hot", "there is often foggy"), individual symbols, monuments, household items, national dishes ("dragon", "Great Wall of China", "chopsticks", "sushi"). In some cases, schoolchildren can name the capital of the state, famous citizens (Jackie Chan, Nikola Tesla, 
Novak Djokovic), express stereotypical ideas about the behaviour of residents (Germans are restrained, Italians are emotional).

An analysis of the statements of schoolchildren shows that their ideas about the cultures and traditions of other countries are fragmented and often formed based on certain stereotypes. After the event, these views become more systematic. Most schoolchildren note that they have learned new and often unexpected things about the countries and people that represent them. The majority of schoolchildren noted that international students aroused sincere sympathy and desire to continue communication and friendship with them.

Comparing the emotional state of schoolchildren and foreign students before and after the event, we can note that representatives of both categories follow the path of rapprochement with each other, overcome fear, excitement, surprise, a tendency to stereotypical perceptions of other people's traditions and, as a result, feel the benefits of mutual communication. Foreigners in most cases note overcoming the fear of misunderstanding, language difficulties, indifference or disinterest on the part of the audience. Russian students report that the cultures of different countries are somewhat similar and, in some aspects, resemble their own. Moreover, those phenomena that are different also deserve attention, as they testify to the diversity of national traditions, the comprehension of which expands the horizons.

The study of the reflection of various categories of project participants allows the organizers to improve the topics and formats of the event continually, maintain an attitude towards interactivity, maximum involvement of schoolchildren in master classes, and their mutual interaction with international students. We are trying to instil these attitudes in foreigners at all stages of the preparation of the event.

It also attracts interest and reflection of teachers who bring students to events and stay with them during presentations and masterclasses. The organizers of the project developed a questionnaire for teachers, who were asked several questions related to understanding the effectiveness of such events, the expediency of their holding, as well as identifying the changes that occur in the minds of students after schoolchildren get acquainted with the cultures and traditions of different countries.

Forty-two teachers from educational institutions in Moscow and the Moscow region took part in the survey.

To the question "How many times have you and your students become participants in the Horizons of Friendship project?" sixteen people (the majority) answered "3 times". Four people visited the project five or more times. The rest took part in one or two events. This result may indicate that the project arouses interest and a desire to participate in it repeatedly.

To the question "When did you decide to participate in the project, what did you expect from it?" teachers noted that their expectations were associated with the opportunity for schoolchildren to learn about different countries not from books, but in the process of live communication with foreigners, broaden their horizons, and get an idea of the diversity of national traditions.

Most of the teachers (37 people) noted that their expectations from the event were fully justified, and only five people chose the wording "were justified to a greater extent" as an answer.

To the question "What surprised/seemed strange / struck you during the event?" Twelve people answered "etiquette", "peculiarities of communication in the family, with friends, with strangers", seven people pointed to national music, dances, five people paid attention to national holidays and the tradition of celebrating the New Year. The rest of the respondents associated their surprise with the national costume, cuisine, "loudness of the voice", "increased emotionality", "smiling", "too short distance" in the process of communication. 
Answering the question "What forms of work with schoolchildren used during the Horizons of Friendship event do you think are the most effective?", The overwhelming majority of respondents pointed to the interactivity of the event and the opportunity to take part in masterclasses. Also, several teachers, as a joyous moment, contributing to the removal of communication barriers between schoolchildren and international students, indicated the possibility of live communication between them, which appears after the completion of the official part of the project, during tea and treat and a joint photo session. Often this communication continues on social media for a long time.

To the question "How has the attitude of your students to the cultures and traditions of other countries changed after participating in the project?" Teachers responded that the project contributed to the career guidance many students (choice of profession linguist, a diploma that, a specialist in cross-cultural communication), driven by the desire to explore their own culture of different peoples, promoted the formation of respect for national traditions of the inhabitants of different countries.

To the questions "Do you need similar projects?" and "Do you plan to participate in the event in the future?" all teachers answered in the affirmative. Thus, the survey showed that from the point of view of the teaching community, the "Horizons of Friendship" project is relevant and in demand, and the forms of its implementation make it possible to effectively solve the tasks assigned to it.

The reflection of school teachers is essential for us to not only as an indicator of the success of the events but also as a confirmation of the idea that the dialogue of cultures in the direct positively coloured communication of their carriers is a significant stimulus for the development of tolerance and intercultural interaction.

\section{Conclusions}

Reflection is an integral part of teaching Russian as a foreign language in general and the considered educational technology - the intercultural educational project "Horizons of Friendship" in particular. Reflection is carried out at almost all stages of the project and by all its participants. Actual introspection during the event is impossible since it would disrupt the course of the event.

The most significant proportion of students 'and teachers' reflection falls on the preparatory stage, during which the teacher works with students - representatives of different linguistic cultures. It stimulates trainees' intercultural reflection (over the contrasts of cultures and languages, the similarities of cultures and their representatives, universal values and the peculiarities of their manifestation in different peoples). Of particular importance here is the student's communicative experience, his impressions and emotional reactions based on this experience. Thus, the actualization and at the same time, the development of the skills of intercultural selfobservation takes place, which makes the process of learning a foreign language and a new culture more conscious.

For educational purposes, it also becomes significant that reflection is carried out both individually and in groups, including in an international group of all project participants. Students consider their reactions against the background of the reactions of representatives of other linguistic cultures, which helps to clarify and verbally formulate their conclusions and observations.

Pedagogical attention to the reflection of the intercultural experience of students enhances the capabilities of the linguodidactic environment: it stimulates the desire of students to immerse themselves in a natural language environment, participate in live communication with native speakers of the host linguistic culture, removes psychological barriers that impede it.

After the event, the reflection of students has a slightly different character: it is a reflection of what happened or, perhaps, did not work out during the event, reflection associated with the assessment of the expectations and 
reality of meeting and communicating with schoolchildren, over the success of overcoming communication barriers, etc. At the same time, the focus of our attention is not so much the individual psychological reactions of the informants, as their responses as representatives of their linguistic culture. Based on the answers to these questions, it is essential for the teacher to compose or expand the portrait of the foreign communicant and to identify how the participation in the project influenced its adaptation in the country, to increase the level of Russian language proficiency. Note that the teachers also go through the self-observation stage again to understand how successful the event was.

No less critical for us is the reflection of the second side of intercultural communication - Moscow schoolchildren and their teachers. Of course, here we cannot talk about full-fledged, complex intercultural reflection due to the brevity of communication with them. However, we consider it necessary to introduce elements of such reflection (before and after the event). For schoolchildren, this project is educational, and their reflection signals some changes in their ideas about representatives of other cultures and the value of intercultural interaction in general. Students begin to understand not only the individual characteristics of different cultures but also identify points of contact between their own traditions and the traditions of other countries. This contributes to the future formation of the interest of Russian schoolchildren in the traditions of different countries and the fostering of tolerance towards their citizens.

\section{References}

Aisman, V. (2018). Crossing Borders: Intercultural Communication in a Global Context: Collection of Materials of the I International Scientific and Practical Conference Identity, language, nation and ethnos. Ethnocentrism and Globalization [Identichnost', yazyk, naciya i etnos. Etnocentrizm i globalizaciya]. Peresekaya granicy: Mezhkul'turnaya kommunikaciya v global'nom kontekste: Sbornik materialov I Mezhdunarodnoj nauchnoprakticheskoj konferencii. Moscow, Gos. IRYA im. A.S. Pushkina. p.10-13.

Azimov, E. \& Shchukin, A. (2018). Modern dictionary of methodological terms and concepts. Theory and practice of teaching languages [Sovremennyj slovar' metodicheskih terminov i ponyatij. Teoriya i praktika obucheniya yazykam]. Moscow, Russkij yazyk. Kursy.

Bibler, V. (1989, July). On the essence of dialogism. Dialogue and Communication [O suti dialogizma. Dialog i kommunikaciya]. Voprosy filosofii, 3-27.

Byram, M. (1997). Teaching and Assessing intercultural competence in language teaching. England: WBC Books Manifacturers Ltd.

Berdichevskij, A. (2012, May). The theory of the modern textbook of Russian as foreign language [K teorii sovremennogo uchebnika RKI]. Russkij yazyk za rubezhom. p. 20-25.

Elizarova, G. (2001). Culture and teaching foreign languages [Kul'tura i obuchenie inostrannym yazykam]. Saint-Petersburg.

Furmanova, V. (1993). Intercultural communication and cultural linguistics in the theory and practice of teaching foreign languages [Mezhkul'turnaya kommunikaciya i lingvokul'turovedenie $\mathrm{v}$ teorii i praktike obucheniya inostrannym yazykam]. Saransk. Izdatelstvo Mordovskogo universiteta.

Introspection as a Methodology in Linguistics. (2007, July) 10th International Cognitive Linguistics Conference. Krakuw (Poland)

Pedersen, P. (2010). Asesing Intercultural Effectiveness Outcomes in a Year-long Study Abroad Program // International Journal of Intercultural Relations. № 34, 70-80.

Khutorskoj, A. (2003). Didactic heuristics. Theory and technology of creative learning [Didakticheskaya evristika. Teoriya i tekhnologiya kreativnogo obucheniya]. Moscow. Izdatelstvo MGU

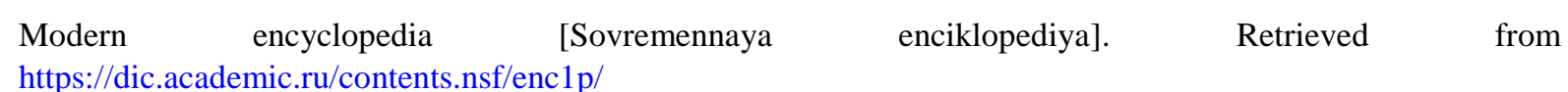

Orekhova, I. (2004). Teaching potential of the Russian language environment in the formation of linguoculturological competence of foreign students. Abstract of dissertation. ... Doctor of Pedagogical 
Sciences [Obuchayushchij potencial russkoj yazykovoj sredy $\mathrm{v}$ formirovanii lingvokul'turologicheskoj kompetencii inostrannyh uchashchihsya: avtoreferat diss. ... d-ra ped.nauk]. M.: Gos. IRYAim. A.S. Pushkina.

Petrikova, A. (2015). Foundations of intercultural didactics [Osnovy mezhkul'turnoj didaktiki]. Moscow, Russkij yazyk. Kursy.

Slobodchikov, V. \& Isaev, E. (1995). Human Psychology [Psihologiya cheloveka]. Moscow

Stepanov, S. (2000). Reflexive practice of creative development of man and organizations [Refleksivnaya praktika tvorcheskogo razvitiya cheloveka i organizacij]. Moscow, Nauka.

Zhukova, A. \& Kudoyarova, T., Leonov, I., Budnik, E. (2020). Intercultural Group Projects as a Pedagogical Technology for Enhancing the Effectiveness of Foreign Language Learning Process. Case Study at the Pushkin State Russian Language Institute. 9th International Conference New Perspectives in Science Education, 222231. doi: 10.26352/E319_2384-950 